PERANCANGAN MEDIA PEMBELAJARAN MENGGAMBAR TEKNIK DENGAN MENGGUNAKAN MACROMEDIA FLASH

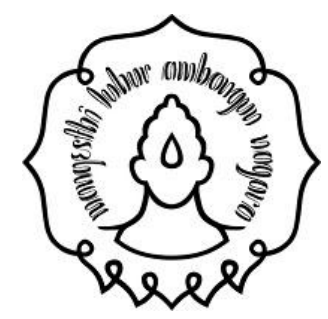

JURNAL

Oleh:

MUH NUR UDIN

K1511029

FAKULTAS KEGURUAN DAN ILMU PENDIDIKAN

UNIVERSITAS SEBELAS MARET

SURAKARTA

2016 


\title{
PERANCANGAN MEDIA PEMBELAJARAN MENGGAMBAR TEKNIK DENGAN MENGGUNAKAN MACROMEDIA FLASH
}

\author{
Muh Nur Udin ${ }^{1}$, Abdul Haris Setiawan ${ }^{2}$ dan Budi Siswanto ${ }^{3}$ \\ Email:muh_nurudin@yahoo.com
}

\begin{abstract}
ABSTRAK
Penelitian ini betujuan untuk: (1) Merancang media pembelajaran menggambar teknik dengan menggunakan Macromedia Flash. (2) Mengetahui tingkat kelayakan media pembelajaran menggambar teknik dengan menggunakan Macromedia Flash. Metode penelitian yang digunakan dalam penelitian ini adalah metode riset dan pengembangan, dengan dilakukan perancangan media pembelajaran. Prosedur perancangan media pembelajaran dilakukan melalui: (1) Tahap studi pendahuluan dilakukan dengan studi literatur dan studi lapangan / observasi. (2) Tahap pengembangan dengan dilakukan pembuatan draft desain model / perancangan yang dibagi menjadi 3 bagian diantaranya: dilakukan penyusunan materi bersama dosen mata kuliah menggambar teknik, pembuatan naskah dan storyboard, pengambilan video, editing video dan penyusunan dalam macromedia flash. Selanjutnya dilakukan validasi penilaian kepada para ahli / pakar materi, media dan pembelajaran untuk menilai kelayakan media pembelajaran yang dibuat. Selanjutnya dilakukan uji coba terbatas dengan 5 mahasiswa yang pernah menempuh mata kuliah menggambar teknik dan uji coba luas kepada 30 mahasiswa PTB FKIP UNS yang pernah menempuh mata kuliah menggambar teknik. (3) Tahap evaluasi merupakan tahap akhir dari proses perancangan terkait model final media pembelajaran menggambar teknik teknik.

Hasil penelitian dari penilaian ahli materi menyatakan bahwa media pembelajaran menggambar teknik layak digunakan dengan persentase sebesar $73 \%$. Penilaian ahli media dengan persentase $91 \%$ menyatakan bahwa perancangan media pembelajaran menggambar teknik termasuk kategori sangat layak. Penilaian ahli pembelajaran menyatakan bahwa perancangan media pembelajaran menggambar teknik layak dengan persentase sebesar $67 \%$ sedangkan uji coba terbatas hasil yang diperoleh sebesar $84 \%$ menyatakan bahwa media pembelajaran yang dirancang sangat layak kemudian pada uji coba luas menyatakan dengan persentase $81 \%$ bahwa media pembelajaran termasuk kategori sangat layak.
\end{abstract}

Kata Kunci: media pembelajaran

\footnotetext{
${ }^{1}$ Mahasiswa Program Studi Pendidikan Teknik Bangunan FKIP UNS

${ }^{2}$ Pembimbing I : Abdul Haris Setiawan, S.Pd., M.Pd.

${ }^{3}$ Pembimbing II : Budi Siswanto, S.Pd., M.Ars.
} 


\title{
DESIGNINNG OF INSTRUCTIONAL MEDIA ON TECHNICAL DRAWING COURSE WITH MACROMEDIA FLASH
}

\author{
Muh Nur Udin ${ }^{1}$, Abdul Haris Setiawan ${ }^{2}$ dan Budi Siswanto ${ }^{3}$ \\ Email:muh_nurudin@yahoo.com
}

\begin{abstract}
The objectives of this study are to: (1) Produce instructional media of technical drawing course with Macromedia Flash. (2) Determine the feasibility of instructional media of technical drawing course with Macromedia Flash. The procedures of designing instructional media were done trough: (1) Preliminary study stage was conducted by literature study and observation (2) the development stage by doing the drafting of model design which was divided into three sections including: preparing the draft of learning material with the lecturer of technical drawing course, creating a script and preparing a storyboard, capturing video, editing video and importing to macromedia flash. Next stage was to validate the assessment to the expert of media and learning material to assess the feasibility of instructional media created. Then, doing the limited testing to 5 students who have took technical drawing course and extensive testing to 30 students who have took technical drawing course. (3) The result stage was the final stage of the design process related to the final model of instructional media on technical drawing course.

The results of the study from the assessment of materials experts stated that instructional media fit for use with a percentage of $73 \%$. Media expert assessment stated that instructional media very feasible with the percentage of $91 \%$. The assessment of learning expert stated that the design of instructional media fit for use with a percentage of $67 \%$ while the limited trial results obtained by $84 \%$ stated that the instructional media which designed was very feasible, then on the extensive trials expressed by the percentage $81 \%$ showed that instructional media was very feasible.
\end{abstract}

Keywords: instructional media

\footnotetext{
${ }^{1}$ Student Structural Engineering Education FKIP UNS

${ }^{2} 1^{\text {st }}$ Tentor: Abdul Haris Setiawan, S.Pd,. M.Pd.

${ }^{3} 2^{\text {nd }}$ Tentor : Budi Siswanto, S.Pd,. M.Ars.
} 


\section{PENDAHULUAN}

Pada pelaksanaan pengajaran, Universitas Sebelas Maret berpedoman pada visi dan misi. Di dalam misi yang pertama disebutkan bahwa Universitas Sebelas Maret adalah penyelenggara pendidikan dan pengajaran yang menuntut pengembangan diri dosen dan mendorong kemandirian mahasiswa dalam memperoleh pengetahuan, keterampilan, dan sikap. Pengajaran yang terlaksana dalam perkuliahan di Pendidikan Teknik Bangunan FKIP UNS tersaji dalam lingkup mata kuliah tertentu, salah satunya adalah mata kuliah Menggambar Teknik.

Mata kuliah Menggambar Teknik merupakan mata kuliah wajib yang harus ditempuh oleh setiap mahasiswa Pendidikan Teknik Bangunan. Mata kuliah Menggambar Teknik bertujuan untuk memberikan pemahaman mengenai dasar menggambar dalam bidang bangunan. Pembelajaran yang sering dilaksanakan oleh dosen adalah menjelaskan di depan kelas tentang cara menggambar, kemudian siswa diberikan tugas untuk dikerjakan secara mandiri maupun berkelompok dan diselesaikan dalam jangka waktu tertentu.

Mahasiswa yang memilih Program Studi Pendidikan Teknin Bangunan berasal dari latar belakang yang berbeda-beda yaitu berasal dari latar belakang Sekolah Menengah Atas atau Madrasah Aliyah dan Sekolah Menengah Kejuruan. Observasi yang telah dilakukan ditemukan bahwa dibutuhkan media pembelajaran yang dapat digunakan untuk belajar mandiri di rumah dan membantu mahasiswa dalam memahami materi dan membantu mahasiswa dalam pengerjaan tugas.

Perkembangan teknologi dapat memberikan peluang bagi para tenaga pendidik untuk menggembangkan kemampuan membagikan ilmu kepada para peserta didik. Hal tersebut sesuai dengan keterangan salah satu pakar pendidikan Anies Baswedan yang dikutip oleh Reza Aditya (2014; 1) menyatakan bahwa dengan adanya pemanfaatan teknologi di lembaga pendidikan, akan mempermudah kegiatan belajar mengajar dan mendorong siswa agar melahirkan karya teknologi.

Tenaga pendidik diharapkan mampu menciptakan proses belajar mengajar yang menarik dan meningkatkan pemahaman peserta didik. Menurut Mulyanta (2012: 2) "Kemampuan pendidik dalam mengembangkan media pembelajaran merupakan salah satu faktor penentu keberhasilan peserta didik dalam mencapai kompetensi yang diharapkan". Oleh karena itu sangat penting bagi para pendidik dapat merancang media pembelajaran yang berguna untuk menunjang keberhasilan peseta didik dalam mencapai kompetensi yang diajarkan.

Pemanfaatan media pembelajaran dengan software macromedia flash sangat tepat apabila digunakan dalam mata kuliah menggambar teknik karena terdapat efekefek audio visual yang diperlukan untuk mempermudah belajar mahasiswa. Hal ini sejalan dengan jenis mata kuliah menggambar teknik yang mengedepankan aspek visual. Ditambah lagi output dari perancangan media ini dapat digandakan kedalam compact disk (CD) sehingga sangat ringkas. Dengan demikian, apabila multimedia pembelajaran dipilih, dikembangkan, digunakan dan dimanfaatkan secara tepat dan baik akan memberi manfaat yang sangat besar bagi dosen dan mahasiswa.

Berdasarkan uraian di atas dengan melihat kondisi permasalahan, maka perlu adanya perancangan media pembelajaran yang dapat membantu mahasiswa dalam memahami materi dan membantu mahasiswa dalam pengerjaan tugas dalam mata kuliah Menggambar Teknik.

\section{KAJIAN PUSTAKA \\ Perancangan}

Agar suatu program atau prosedur dapat berjalan lancar dan memuaskan maka dibutuhkan perancangan yang matang, dan pembuatan keputusan yang tepat menjadi salah satu faktor penentu dalam sebuah perancangan. Perancangan (planning) 
merupakan pemilihan atau penetapan tujuan organisasi dan penentuan strategi, kebijaksanaan, proyek, program, prosedur, metode, sistem, anggaran dan standar yang dibutuhkan untuk mencapai tujuan.

\section{Media Pembelajaran}

Media pembelajaran merupakan salah satu bentuk pemanfaatan teknologi dalam dunia pendidikan, sehingga akan banyak sekali manfaat yang dapat diambil dari pemakaian media pembelajaran. Salah satu manfaatnya adalah memberikan penjelasan yang lebih konkrit karena materi disajikan dengan logis dan jelas, baik media pembelajaran berupa gambar, foto, miniatur, film, video, CD interaktif, komputer dan lain sebagainya. Selain itu media pembelajaran dapat meningkatkan motivasi siswa dalam mengikuti kegiatan pembelajaran, dalam hal ini sesuai dengan pendapat yang dikemukakan oleh Azhar Arsyad (2009: 25) "Media pembelajaran dapat memperjelas penyajian pesan dan informasi sehingga dapat memperlancar dan meningkatkan proses dan hasil belajar".

\section{Multimedia dalam Pembelajaran.}

Menurut Oetomo (2002: 109), secara umum multimedia diartikan sebagai kombinasi teks, gambar, seni grafik, animasi, suara dan video. Aneka media tersebut digabungkan menjadi satu kesatuan kerja yang akan menghasilkan suatu informasi yang tidak hanya dapat dilihat sebagai hasil cetakan, melainkan juga dapat didengar, membentuk simulasi dan animasi yang dapat membangkitkan minat dan memiliki nilai seni grafis yang tinggi dalam penyajiannya. Ariani dan Haryanto (2010: 25) mengemukakan bahwa multimedia terbagi menjadi dua kategori, yaitu: multimedia linier dan multimedia interaktif. Multimedia linier adalah suatu multimedia yang tidak dilengkapi dengan alat pengontrol apapun yang dapat dioperasikan oleh pengguna. Multimedia ini berjalan sekuensial (berurutan). Multimedia interaktif adalah suatu multimedia yang dilengkapi dengan alat pengontrol yang dapat dioperasikan oleh pengguna sehingga pengguna dapat memilih apa yang dikehendaki untuk proses selanjutnya.

\section{Perancangan Media Pembelajaran}

Dalam perancangan media pembelajaran ada beberapa tahapan yang harus dijalankan, Urbani dan Purnama (2012: 118) mengemukakan perumusan langkah produksi sinema berbasis multimedia terdiri dari proses pra produksi, produksi, dan pasca produksi.

\section{Menggambar Teknik}

Mata kuliah menggambar teknik merupakan mata kuliah yang berisi dasardasar dari menggambar teknik yang harus dikuasai oleh mahasiswa pendidikan teknik bangunan, yang diberikan pada semester satu. Salah satu tujuan pembelajaran yang dicapai yaitu mampu memahami, menerapkan gambar dan lebih mengembangkan hasil karya gambarnya sesuai konstruksi kaidah-kaidah gambar teknik yang benar. Dimana salah satu kompetensi dasarnya adalah mahasiswa mampu menggambar proyeksi.Materi yang disajikan pada mata kuliah menggambar teknik menggambar proyeksi adalah: (a) pengertian proyeksi, (b) proyeksi titik, (c) proyeksi garis, (d) proyeksi bidang, (e) proyeksi benda.

\section{Macromedia Flash Profesional 8}

Perancangan media pembelajaran dalam penelitian ini menggunakan perangkat lunak (software) macromedia flash profesional 8 dalam perancangannya. macromedia flash profesional 8 merupakan sebuah program aplikasi standar yang dikeluarkan oleh perusahaan internasional Macromedia, program ini digunakan untuk merancang grafis animasi dan audio visual.

\section{METODE PENELITIAN}

\begin{tabular}{lllr}
\multicolumn{2}{c}{ Dalam melaksanakan penelitian } \\
diperlukan tempat penelitian untuk \\
memperoleh & data-data yang mendukung
\end{tabular}


tercapainya tujuan penelitian, tempat penelitian ini dilaksanakan di Program Studi Pendidikan Teknik Bangunan FKIP UNS. Waktu penelitian dilaksanakan antara periode bulan April 2015 - April 2016.

Penelitian ini mengambil dosen yang merupakan ahli dari masing-masing bidang, antara lain; ahli dalam bidang menggambar teknik, bidang media dan bidang pembelajaran sebagai dosen yang memberikan penilaian terhadap kelayakan media pembelajaran menggambar teknik.

Pengujian juga dilakukan terhadap pengguna media pembelajaran yaitu mahasiswa yang telah menempuh mata kulian menggambar teknik untuk menilai kelayakan media pembelajaran.

Metode yang dipakai oleh peneliti adalah metode penelitian dan pengembangan (Research and Depelopment). Adapun penelitian yang akan dikembangkan adalah media pembelajaran. Prosedur perancangan mengikuti metode research and development Sugiyono (2014: 409) dijelaskan pada gambar 1

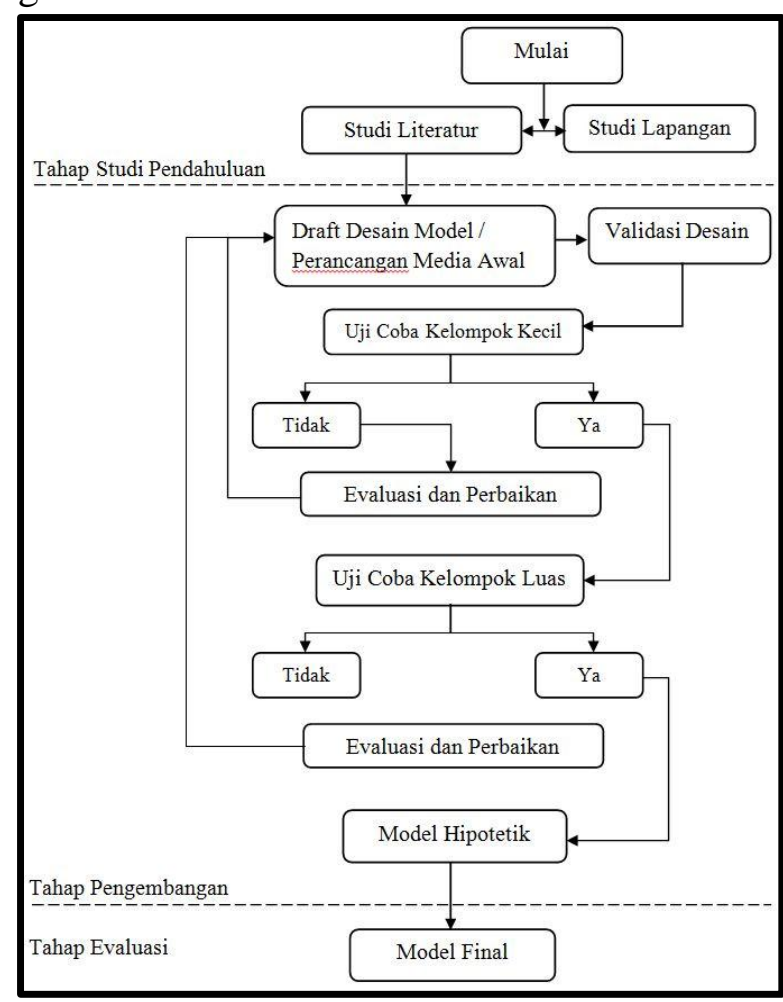

Gambar 1. Prosedur Perancangan

Penelitian ini dianalisis secara statistik deskriptif untuk mendapatkan hasil penelitian pengembangan. Kategori kelayakan media pembelajaran ini dipakai skala pengukuran skala likert. Variabel yang akan diukur, dijabarkan menjadi indikator variabel. Kemudian indikator variabel dijadikan sebagai titik tolak untuk menyusun item-item instrumen yang dapat berupa pernyataan atau pertanyaan. Jawaban setiap item instrumen yang menggunakan skala likert mempunyai gradasi dari sangat positif sampai sangat negatif Dapat dijelaskan pada tabel 2 dan 3 sebagai berikut :

Tabel 2. Kriteria Penilaian Kelayakan

\begin{tabular}{ll}
\hline Kategori Penilaian & Skor \\
\hline Sangat layak & 5 \\
Layak & 4 \\
Cukup Layak & 3 \\
Tidak Layak & 2 \\
Sangat Tidak Layak & 1 \\
\hline
\end{tabular}

Tabel 3. Interprestasi Hasil Penelitian

\begin{tabular}{|c|c|}
\hline Kategori Penelitian & Interprestasi \\
\hline Sangat Layak & $\begin{array}{l}\text { Ahli materi, ahli media dan ahli pembelajaran } \\
\text { menyatakan bahwa media pembelajaran } \\
\text { berbasis video sangat layak digunakan sebagai } \\
\text { media pembelajaran. }\end{array}$ \\
\hline Layak & $\begin{array}{l}\text { Ahli materi, ahli media dan ahli pembelajaran } \\
\text { menyatakan bahwa media pembelajaran } \\
\text { berbasis video layak digunakan sebagai media } \\
\text { pembelajaran. }\end{array}$ \\
\hline Cukup Layak & $\begin{array}{l}\text { Ahli materi, ahli media dan ahli pembelajaran } \\
\text { menyatakan bahwa media pembelajaran } \\
\text { berbasis video cukup layak digunakan sebagai } \\
\text { media pembelajaran. }\end{array}$ \\
\hline Tidak Layak & $\begin{array}{l}\text { Ahli materi, ahli media dan ahli pembelajaran } \\
\text { menyatakan bahwa media pembelajaran } \\
\text { berbasis video tidak layak digunakan sebagai } \\
\text { media pembelajaran. }\end{array}$ \\
\hline $\begin{array}{c}\text { Sangat Tidak } \\
\text { Layak }\end{array}$ & $\begin{array}{l}\text { Ahli materi, ahli media dan ahli pembelajaran } \\
\text { menyatakan bahwa media pembelajaran } \\
\text { berbasis video sangat tidak layak digunakan } \\
\text { sebagai media pembelajaran. }\end{array}$ \\
\hline
\end{tabular}

Proses perhitungan persentase dilakukan dengan cara membandingkan frekuensi yang diperoleh dengan frekuensi yang diharapkan. Persentase dihitung dengan menggunakan rumus sebagai berikut:

Presentase $=\underline{\text { Frekuensi yang diperoleh }} \times 100$ Frekuensi yang diharapkan 


\section{HASIL PENELITIAN}

\section{Tahap Studi Pendahuluan}

Pada tahap studi pendahuluan, peneliti mengumpulkan referensi maupun pustaka terkait mata kuliah menggambar teknik khususnya materi proyeksi. Mengumpulkan materi mengenai bagaimana cara menggunakan program macromedia flash. Peneliti juga melakukan wawancara terhadap dosen pengampu mata kuliah mengambar teknik untuk menggali informasi. Tahap ini terlaksana pada rentang waktu Mei - September 2015.

\section{Tahap Perancangan}

Peneliti menyusunan draft materi mata kuliah menggambar teknik menggunakan acuan pada silabus. Penyusunan draft materi dalam perancangan media pembelajaran dilakukan dalam bimbingan dosen pengampu mata kuliah menggambar teknik. Dalam tahap ini peneliti menyusun batasan materi materi menggambar teknik dalam sebuah catatan dan kemudian di kembangkan dalam penyusunan naskah materi.

Selanjutnya peneliti membuat naskah materi untuk menjelaskan isi materi dalam media pembelajaran. Naskah materi ini merupakan bentuk pengembangan dari draft naskah yang telah disusun oleh peneliti pada tahap sebelumnya.

Langkah selanjutnya adalah membuat storyboard yaitu keterangan visual yang disusun berurutan sesuai dengan naskah, dengan penyusunan storyboard maka penyampaian ide materi pembelajaran yang terkandung dalam media pembelajaran akan menjadi lebih mudah.

Pengambilan video merupakan proses penting dalam perancangan media pembelajaran menggambar teknik karena video merupakan isi dari media pembelajaran yang akan dirancang. Pengambilan video menggunakan seperangkat laptop, mouse dan headset.

Peneliti mempraktekkan langsung materi menggambar teknik proyeksi dengan bantuan program google sketchup untuk ilustrasi yang membutuhkan pandangan secara 3 dimensi, dan menggunakan program autocad untuk membuat ilustrasi yang mengutamakan pada kejelasan notasi gambar. Pada saat yang sama, tampilan pada layar monitor akan direkam dengan bantuan program camtasia studio sebagai program perekam aktifitas yang tampak dalam tampilan layar monitor. Program camtasia studio juga sekaligus merekam narasi yang dibacakan peneliti saat membuat ilustrasi materi menggambar teknik. Ilustrasi yang di praktekkan mengacu pada draft desain media yang sudah disusun sebelumnya dengan bimbingan dosen pengampu mata kuliah menggambar teknik.

Video yang sudah selesai di edit kemudian dikemas dengan program macromedia flash agar menjadi media pembelajaran yang dapat membantu mahasiswa belajar secara mandiri dirumah.

Tampilan pembuka merupakan tampilan awal yang muncul saat media pembelajaran dibuka pertama kali. Tampilan pembuka dibuat sederhana dengan memperlihatkan judul media pembelajaran menggambar teknik. Pada tampilan pembuka ini hanya ditampilkan 2 tombol yakni tombol "Petunjuk Penggunaan" dan tombol "Mulai". Video cara penggunaan media akan terbuka apabila tombol "Petunjuk Penggunaan" di klik. Apabila tombol "Mulai" diklik maka frame materi akan terlihat.

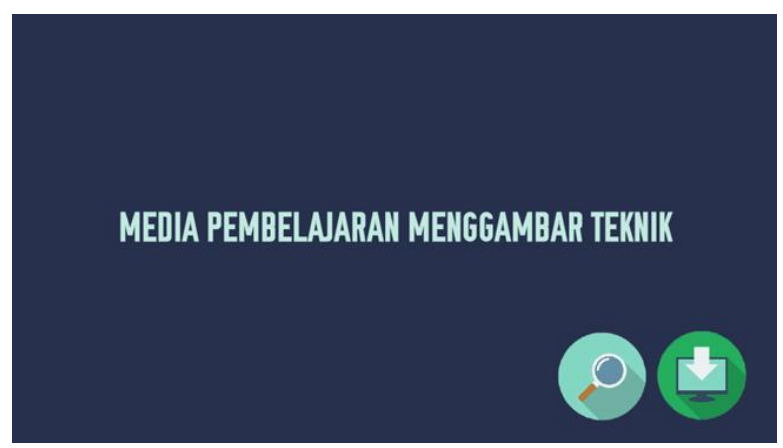

Gambar 2. Tampilan Pembuka

Apabila tombol "Petunjuk Penggunaan" diklik, maka video petunjuk cara penggunaan akan mulai ditampilkan. Video yang ditampilkan adalah video yang 
dirancang agar mahasiswa pengguna media pembelajaran menggambar teknik mengetahui langkah-langkah pengoperasian media pembelajaran.

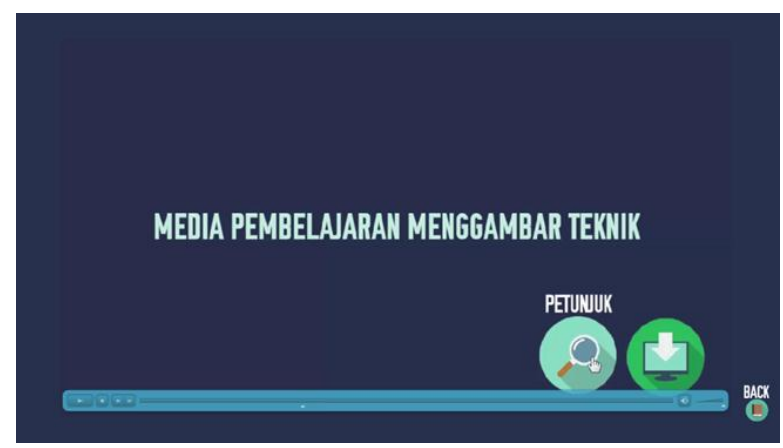

Gambar 3. Tampilan Petunjuk

Setelah pengguna menekan tombol "Mulai" maka pengguna akan melihat menu inti yang berisi beberapa tombol yang memiliki fungsi masing-masing.

Sebelum pengguna media melihat isi materi yang tersedia dalam video, pengguna akan terlebih dahulu melihat menu silabus. Menu silabus berisi silabus yang diperoleh dari dosen pengampu mata kuliah menggambar teknik. Dengan melihat silabus, pengguna diharapkan mampu mengetahui batasan-batasan materi yang dipelajari dalam media pembelajaran menggambar teknik.

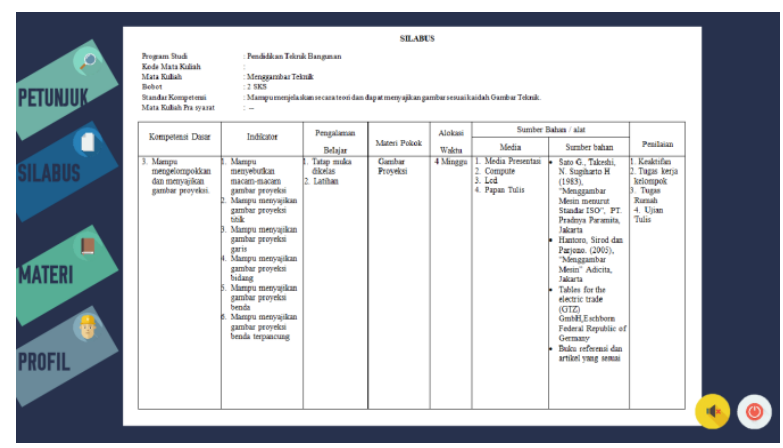

Gambar 4. Tampilan Menu Silabus

Setelah pengguna media melihat petunjuk penggunaan dan silabus, selanjutnya pengguna akan melihat menu materi. Pada menu materi akan muncul 9 macam tombol yang masing-masing tombol akan menuju materi yang berbeda sesuai dengan nama tombol.

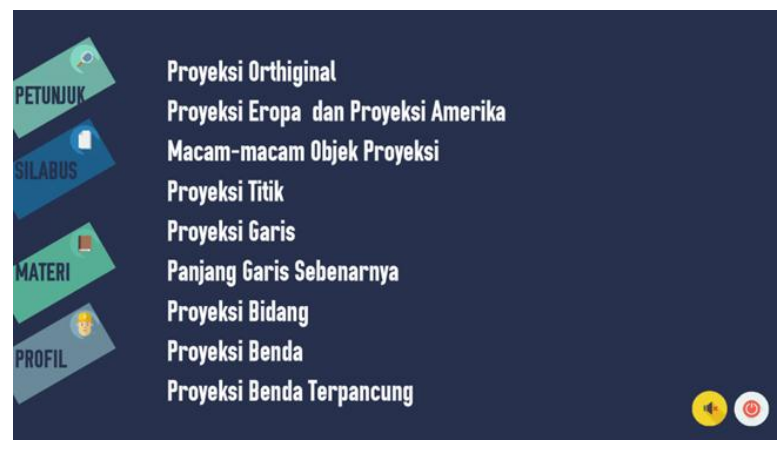

Gambar 5. Tampilan Menu Materi

Pada menu profil, pengguna dapat melihat pihak-pihak yang terkait dalam skripsi perancangan media pembelajaran menggambar teknik

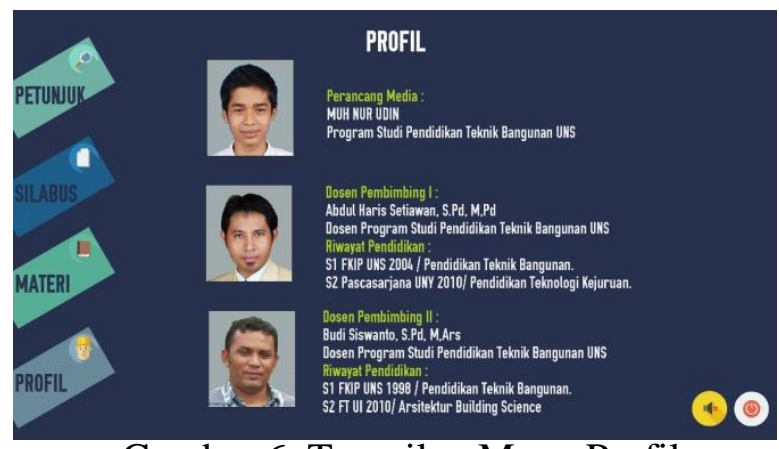

Gambar 6. Tampilan Menu Profil

Apabila pengguna ingin menutup media pembelajaran menggambar teknik maka pengguna hanya perlu menekan tombol keluar, kemudian tampilan menu keluar akan tampil. Tampilan menu keluar akan berisi kalimat pertanyaan "Apakah anda yakin ingin keluar", dan ada 2 tombol yakni tombol "Tidak" dan tombol "Ya". Dengan menekan tombol "Ya" maka media pembelajaran akan tertutup. Apabila pengguna menekan tombol "Tidak" maka pengguna akan kembali menuju menu "Materi".

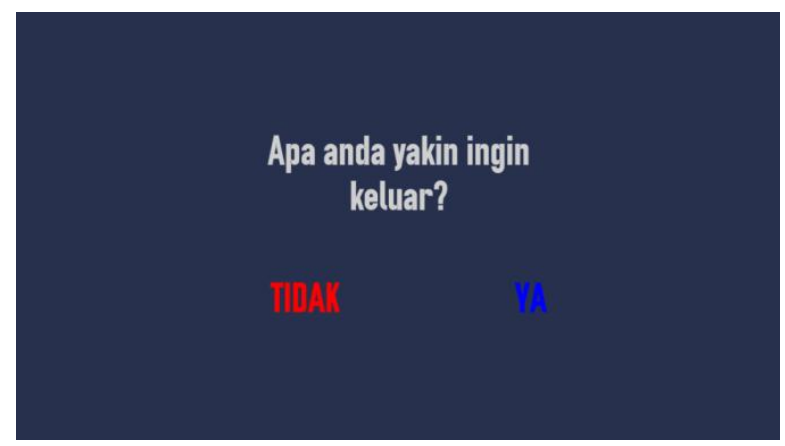

Gambar 7. Tampilan Menu Keluar 
Validasi Tim Ahli (expert judgement)

Pakar materi yang menilai adalah dosen pengampu mata kuliah menggambar teknik yang berkompeten pada bidang menggambar teknik, untuk menilai relevansi materi dalam produk media pembelajaran yang akan dijadikan acuan untuk revisi produk media pembelajaran yang telah dirancang. Pengujian terlaksana pada tanggal 28 desember 2015 di Kampus V FKIP UNS. Sebanyak 30 butir pertanyaan yang ditinjau dari beberapa aspek atau indikator

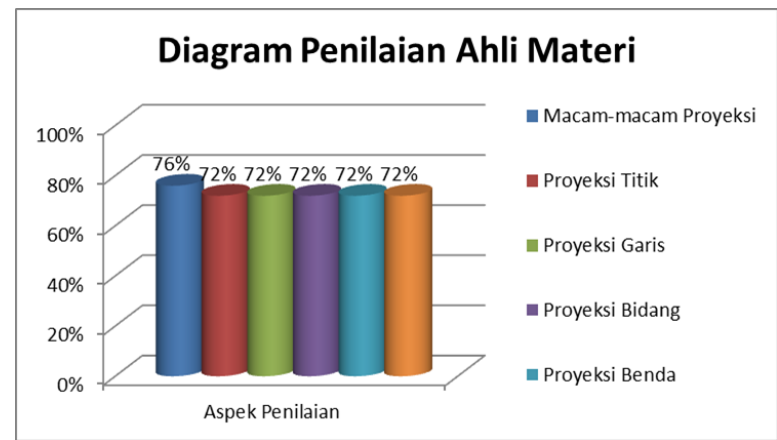

Gambar 8. Diagram Penilaian Ahli Materi

Pakar media pada media pembelajaran ini adalah dosen multimedia Pendidikan Teknik Informatika dan Komputer FKIP UNS untuk menilai unsur mutu teknis, unsur komposisi, unsur keseimbangan dan unsur keterpaduan. Pengujian terlaksana pada tanggal 31 desember 2015 di Kampus V FKIP UNS.Sebanyak 23 butir pertanyaan yang ditinjau dari beberapa aspek atau indikator.

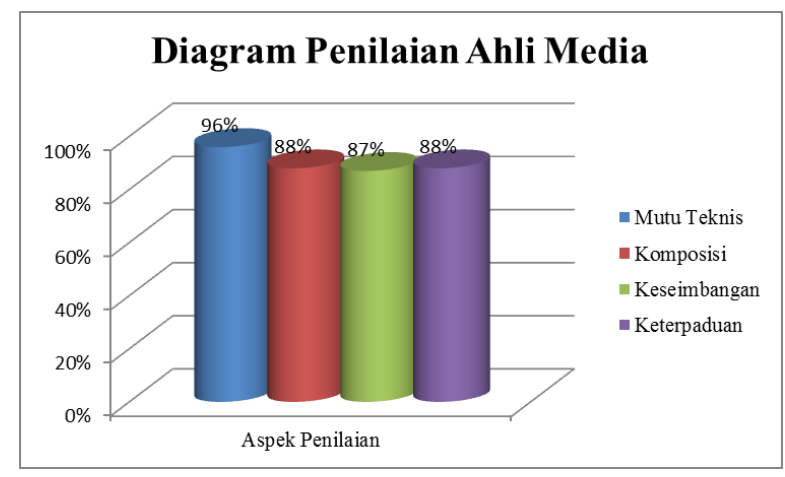

Gambar 9. Diagram Penilaian Ahli Media

Pakar pembelajaran pada media pembelajaran ini adalah dosen pembelajaran pada Pendidikan Teknik Bangunan FKIP UNS yang berkompeten dalam bidang pembelajaran untuk menilai unsur tujuan, unsur ketepatgunaan, unsur mutu teknis, unsur tingkat kemampuan siswa, dan unsur manfaat. Pengujian terlaksana pada tanggal 31 desember 2015 di Kampus V FKIP UNS. Sebanyak 21 butir pertanyaan yang ditinjau dari beberapa aspek atau indikator.

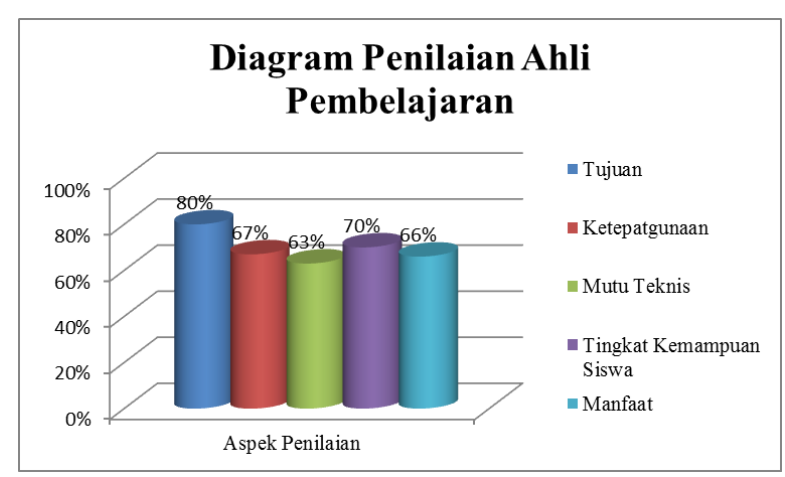

Gambar 10. Penilaian Ahli Pembelajaran

Uji coba terbatas dilakukan setelah tahap revisi tim ahli. Pengujian terlaksana pada tanggal 5 januari 2015 di Kampus V FKIP UNS. Uji coba terbatas diterapkan kepada 5 mahasiswa Pendidikan Teknik Bangunan FKIP UNS yang pernah menempuh mata kuliah menggambar teknik. Uji coba terbatas dilakukan dengan memutar media pembelajaran dengan menggunakan proyektor di depan kelas untuk dinilai oleh pengguna. Pengguna dalam uji coba terbatas menilai kelayakan hasil perancangan media pembelajaran menggambar teknik yang dirancang oleh peneliti.

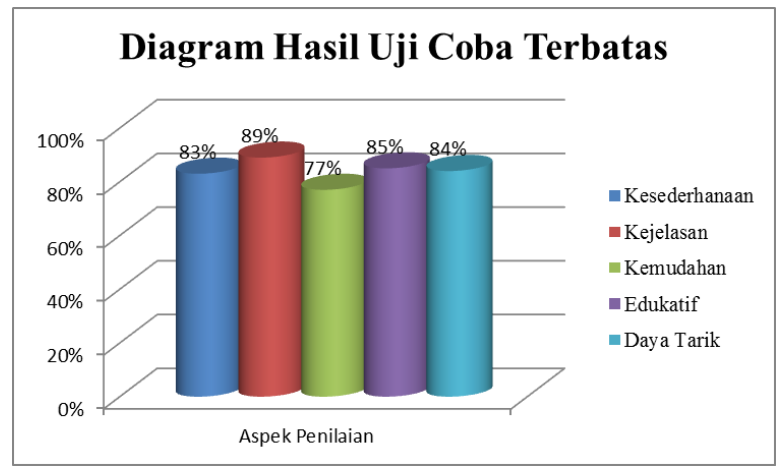

Gambar 11. Hasil Uji Coba Terbatas

Uji coba luas dilakukan setelah melakukan uji coba terbatas. Uji coba luas media pembelajaran menggambar teknik dilaksanakan dengan responden 30 
mahasiswa Pendidikan Teknik Bangunan yang sudah pernah menempuh mata kuliah menggambar teknik. Pengujian terlaksana pada tanggal 6 januari 2016 di Kampus V FKIP UNS. Uji kelayakan disusun berdasarkan indikator kelayakan media sesuai dengan instrumen penilaian media yang sudah dikembangkan. Data yang diperoleh dari penilaian adalah tanggapan pengguna media terhadap hasil media yang telah dirancang.

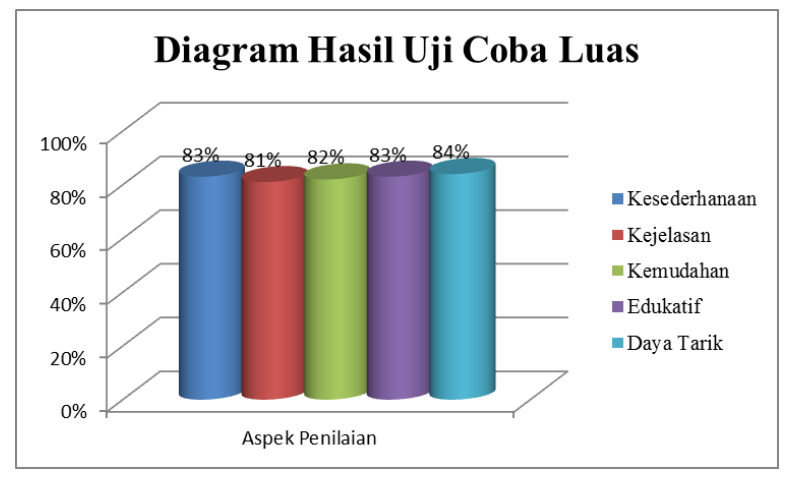

Gambar 12. Hasil Uji Coba Luas

\section{PEMBAHASAN}

Pada tahap studi pendahuluan peneliti mengolah materi dan hasil informasi yang didapatkan pada tahap studi pendahuluan kemudian disusun dalam draft desain media pembelajaran. Penyusunan draft desain yang harus disusun antara lain; penyusunan draft materiPenyusunan naskah materi, penyusunan storyboard. Peneliti harus paham mengenai apa yang akan dirancang, tentang materi menggambar teknik dan cara penggunaan programprogram yang mendukung proses perancangan.

Pada tahap pengambilan video menggunakan bantuan program camtasia. Sedangkan untuk membuat ilustrasinya menggunakan bantuan program google sketchup dan autocad. Peneliti menentukan apa yang menjadi penekanan yang ingin disampaikan melalui video pembelajaran ini, apabila menekankan pandangan 3 dimensi maka digunakan program google sketchup. Apabila video lebih menekankan pada penggunaan notasi gambar maka program autocad yang digunakan.

Hasil pengambilan video kemudian disempurnakan dengan program camtasia. Pada tahap ini video diberi kelengkapankelengkapan seperti teks judul, animasi opening, background music.

Agar pengguna media dapat dengan mudah memutar video, maka perlu disusun dalam tampilan yang sederhana. Tampilan tampilan yang tersedia dalam media pembelajaran menggambar teknik antara lain; tampilan pembuka, tampilan menu inti, tampilan menu petunjuk, menu silabus, menu materi, menu profil dan tampilan menu keluar.

Setelah draft media selesai dirancang maka draft media ini harus melalui serangkaian pengujian untuk mengetahui kelayakan media.

Pengujian media dari sudut pandang ahli materi diperoleh rata-rata skor sebesar $73 \%$ (layak), dengan rincian hasil sebagai berikut; relevansi materi macam-macam proyeksi mendapatkan skor sebesar $73 \%$, relevansi materi proyeksi titik sebesar $72 \%$, relevansi materi proyeksi garis sebesar $72 \%$, relevansi materi proyeksi bidang sebesar $72 \%$, relevansi materi proyeksi benda sebesar $72 \%$, relevansi materi proyeksi benda terpancung sebesar $72 \%$. Pada pengujian ini ahli materi memberikan saran agar memperhatikan kelengkapan notasi dalam gambar.

Dosen IT ditunjuk sebagai sebagai pakar media yang memberi penilaian terhadap media pembelajaran menggambar teknik. Pada pengujian ahli media ini diperoleh rata-rata skor sebesar $91 \%$, dengan rincian hasil sebagai berikut; mutu teknis mendapatkan skor sebesar 96\% (sangat layak), komposisi sebesar 88\%, keseimbangan sebesar 87\%, keterpaduan $88 \%$. Pada pengujian ini ahli media memberikan saran agar dalam media pembelajaran ditambah "sitemap" untuk memudahkan pemahaman terhadap isi media. 
Dosen pembelajaran ditunjuk sebagai pakar pembelajaran yang memberi penilaian terhadap media pembelajaran menggambar teknik. Pada uji ahli pembelajaran ini diperoleh rata-rata skor sebesar 67 (layak)\%, dengan rincian hasil sebagai berikut. Dari segi aspek tujuan mendapatkan skor sebesar $80 \%$, ketepatgunaan sebesar $67 \%$, mutu teknis sebesar 63\%, tingkat kemampuan siswa 70\%, manfaat sebesar 66\%. Pada pengujian ini ahli pembelajaran memberi saran agar dalam media pembelajaran ditambahkan uraian mengenai tujuan pembelajaran.

Uji coba terbatas dilakukan dengan mengambil 5 mahasiswa PTB FKIP UNS yang pernah mengambil mata kuliah menggambar teknik. Pada uji coba tarbatas ini diperoleh rata-rata skor $84 \%$ (sangat layak), dengan rincian sebagai berikut; dari segi aspek kesederhanaan diperoleh skor sebesar 83\%,kejelasan sebesar 89\%, kemudahan sebesar $77 \%$, edukatif sebesar $85 \%$, daya tarik sebesar $84 \%$.

Uji coba terbatas dilakukan dengan mengambil 30 mahasiswa PTB FKIP UNS yang pernah mengambil mata kuliah menggambar teknik. Pada uji coba tarbatas ini diperoleh rata-rata skor $81 \%$, dengan rincian sebagai berikut; dari segi aspek kesederhanaan diperoleh skor sebesar 83\%, kejelasan sebesar $81 \%$, kemudahan sebesar $82 \%$, edukatif sebesar $83 \%$, daya tarik sebesar $84 \%$.

\section{KESIMPULAN}

Dalam penelitian perancangan media dapat disimpulkan bahwa prosedur perancangan media pembelajaran pada mata kuliah menggambar teknik diperlukan proses pembuatan ilustrasi terlebih dahulu menggunakan program google sketchup pada saat membuat ilustrasi yang mengutamakan pandangan secara 3 dimensi, dan menggunakan program autocad saat membuat ilustrasi yang memerlukan penekanan pada pemberian notasi gambar.
Kelayakan media pembelajaran menggambar teknik diketahui berdasarkan validasi penilaian ahli materi, ahli media, ahli pembelajaran dan mahasiswa

Kelayakan media pembelajaran berdasarkan pakar ahli materi menyatakan bahwa perancangan media pembelajaran pada mata kuliah menggambar teknik termasuk kedalam kategori layak.

Kelayakan media pembelajaran berdasarkan pakar ahli media menyatakan bahwa perancangan media pembelajaran menggambar teknik pada mata kuliah menggambar teknik termasuk kedalam kategori sangat layak.

Kelayakan media pembelajaran berdasarkan pakar ahli pembelajaran menyatakan bahwa perancangan media pembelajaran menggambar teknik pada mata kuliah menggambar teknik termasuk kedalam kategori layak.

Kelayakan media pembelajaran berdasarkan pendapat 5 mahasiswa PTB FKIP UNS yang pernah menempuh mata kuliah menggambar teknik. Hasil uji coba perancangan media pembelajaran pada mata kuliah menggambar teknik termasuk kedalam kategori sangat layak.

Kelayakan media pembelajaran berdasarkan pendapat 30 mahasiswa PTB FKIP UNS yang pernah menempuh mata kuliah menggambar teknik. Hasil uji coba skala luas perancangan media pembelajaran pada mata kuliah menggambar teknik termasuk kedalam kategori sangat layak.

\section{SARAN}

Berdasarkan simpulan dan implikasi di atas, peneliti dapat mengemukakan beberapa saran sebagai berikut:

1. Dalam penggunaan macromedia flash sebagai program perancangan media pembelajaran sebaiknya disusun dengan timeline yang sederhana, backsound yang nyaman didengar oleh pengguna dan dipilih background yang membuat tampilan media pembelajaran menjadi lebih jelas. 
2. Kedepan bagi peneliti yang ingin mengembangkan media pembelajaran dengan program macromedia flash agar merancang inovasi-inovasi untuk membuat media lebih interaktif

3. sebaiknya dalam media pembelajaran ditambahkan kuis atau latihan soal agar membuat pengguna berinteraksi dengan media pembelajaran dan membuat media menjadi bersifat dua arah.

4. Saran untuk penelitian selanjutnya agar dilakukan penelitian mengenai penggunaan media pembelajaran untuk meningkatkan prestasi belajar peserta didik.

\section{DAFTAR PUSTAKA}

Almekhlafi, A.G. (2006). Effectiveness of Interactive Multimedia Environment on Language Acquisition Skills of 6th Grade Students in the United Arab Emirates. International Journal of Instructional Media, 33(4), 427-441.

Ariani, N. \& Haryanto, D. (2010). Pembelajaran Multimedia di Sekolah. Jakarta: PT. Prestasi Pustakaraya.

Azhar Arsyad. (2009). Media Pembelajaran. Jakarta: Raja Grafindo Persada.

Mulyanta. (2012). Tutorial Membangun Multimedia Interaktif Media Pembelajaran. Yogyakarta: Universitas Atmajaya Yogyakarta

Oetomo, B.S.D. (2002). E-education; Konsep Teknologi dan Aplikasi Internet Pendidikan. Yogyakarta: Andi.

Sugiyono. (2013) Metode Penelitian Pendidikan. Bandung: Alfabeta.

Sugiyono. (2014). "Metode Penelitian Pendidikan Pendekatan Kuantitatif Kualitatif dan R\&D”. Bandung: Alfabeta.
Urbani, Y.H. \& Purnama, B.E. (2012). Produksi Film Indie Komersial "Aku Cinta Indonesia - Generation" Berbasis Multimedia. Indonesian Jurnal on Computer Science Speed. 9 (3) 118.

Reza Aditya (2014). Anies Baswedan Dorong Pendidikan Bebasis Teknologi. Diperoleh 02 Mei 2015 dari http://www.indopos.co.id/2014/12/ani es-baswedan-dorong-pendidikanbebasis-teknologi.html 